\title{
Apple polygalacturonase inhibiting protein1 expressed in transgenic tobacco inhibits polygalacturonases from fungal pathogens of apple and the anthracnose pathogen of lupins
}

\author{
Dean Oelofse, Ian A. Dubery, Riaan Meyer, Melanie S. Arendse, Inge \\ Gazendamand Dave K. Berger
}

\begin{abstract}
Extracts from apple fruit (cultivar "Granny Smith") inhibited the cell-wall degrading polygalacturonase (PG) activity of Colletotrichum lupini, the causal agent of anthracnose on lupins, as well as Aspergillus niger PG. Southern blot analysis indicated that this cultivar of apple has a small gene family of polygalacturonase inhibiting proteins (pgips), and therefore heterologous expression in transgenic tobacco was used to identify the specific gene product responsible for the inhibitory activity. A previously isolated pgip gene, termed Mdpgip1, was introduced into tobacco (Nicotiana tabacum) by Agrobacterium-mediated transformation. The mature MdPGIP1 protein was purified to apparent homogeneity from tobacco leaves by high salt extraction, clarification by DEAE-Sepharose and cation exchange HPLC. Purified MdPGIP1 inhibited PGs from C. lupini and PGs from two economically important pathogens of apple trees, Botryosphaeria obtusa and Diaporthe ambigua. It did not inhibit the A. niger PG, which was in contrast to the apple fruit extract used in this study. We conclude that there are at least two active PGIPs expressed in apple, which differ in their charge properties and ability to inhibit $A$. niger PG.
\end{abstract}

\section{Graphical abstract}

Biochemical characterization of the apple polygalacturonase inhibiting protein1 was carried out by expression in a heterologous plant host, thus defining the activity of the product of this specific apple pgip gene.

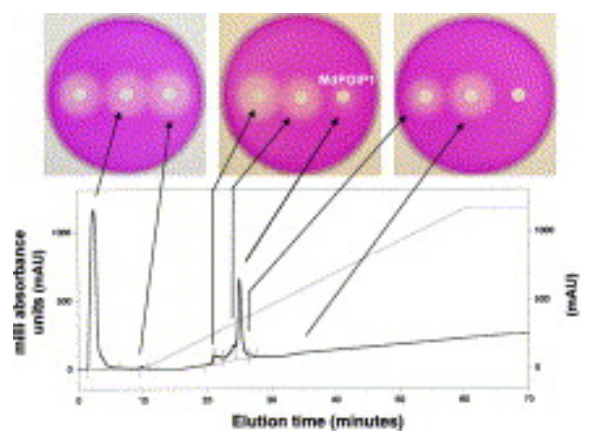




\section{Article Outline}

1. Introduction

2. Results

2.1. PGIP from fruit of apple cv. Granny Smith inhibits the PGs from C. lupini and A. niger

2.2. Apple cv. Granny Smith has at least two pgip gene copies

2.3. MdPGIP1 extracts from transgenic tobacco inhibit $C$. lupini PGs

2.4. Purification of active MdPGIP1 to apparent homogeneity from transgenic tobacco

2.5. Purified MdPGIP1 inhibits PGs from C. lupini, B. obtusa and D. ambigua

3. Discussion

4. Experimental

4.1. Fungal cultures and plant materials

4.2. Growth of fungi for preparation of PG extracts

4.3. DNA blot analysis

4.4. Construction of Mdpgip1 binary vector for tobacco transformation

4.5. Tobacco transformation

4.6. PCR screening of Mdpgip1 transgenic tobacco

4.7. Preparation of PGIP extracts from apple fruit and transgenic tobacco expressing the Mdpgip1 gene

4.8. Purification of MdPGIP1 from transgenic tobacco

4.9. Characterisation of the MdPGIP1 using SDS-PAGE and native IEF-PAGE

4.10. N-terminal amino acid sequencing

Acknowledgements

References

\section{Introduction}

Plants posses a polysaccharide-rich cell wall that acts as a barrier to pathogenic fungi (De Lorenzo et al., 2001). Fungal endo polygalacturonases (PGs) are implicated as important enzymes in the early stages of plant pathogenesis (Albersheim and Anderson, 1971), and have been shown to be among the first enzymes to be secreted by fungi growing on plant cell wall material in vitro (English et al., 1971). The action of endo PGs is sometimes a prerequisite for cell wall degradation by other enzymes since it was demonstrated that PGs were necessary before other enzymes such as glycosidases, cellulases, and hemicellulases could degrade cell wall polysaccharides (Karr and Albersheim, 1970). The degradation of the cell wall leads to host tissue maceration, providing nourishment for the invading fungus (Cook et al., 1999). 
Plant polygalacturonase inhibiting proteins (PGIPs) are cell wall-associated glycoproteins that can effectively inhibit the fungal endo PGs (De Lorenzo et al., 2001), but no interaction occurs with fungal exo PGs and pectin lyases or endo PGs of bacterial or plant origin. PGIPs have been identified in various tissue types from a variety of monocotyledonous and dicotyledonous plant species of which only a few have been purified to homogeneity (De Lorenzo et al., 2001).

Various plant species have been shown to possess multiple PGIPs (Desiderio et al., 1997). These PGIPs have different specificities against different fungal PGs. Leckie et al. (1999) demonstrated that both Phaseolus vulgaris PGIP-1 (PvPGIP-1) and PvPGIP-2 were effective in their ability to inhibit Aspergillus niger PG, whereas only PvPGIP-2 was able to inhibit Fusarium moniliforme PG.

An apple PGIP has previously been purified and partially characterised from mature 'Golden Delicious' fruit (Malus domestica Borkh) (Yao et al., 1995), and the sequence of a pgip gene from Golden Delicious apples was submitted to Genbank (Accession no. U77041) (Yao et al., 1999). However, since plants express more than one PGIP, the protein purified by these authors could be encoded by any one of at least two closely related copies of pgip genes found in apple. An apple pgip gene, with a predicted gene product identical to that of the one from Golden Delicious apples, has been isolated from cultivar Granny Smith (Arendse et al., 1999) and was designated Mdpgip1.

The aim of the study was to determine if the activity of PGIP in apple fruit could be attributed to the product of Mdpgip1, since previous studies had not linked PGIP activity to a particular gene in apple. Expression in the heterologous system of transgenic tobacco was used for this purpose. This study describes the purification and characterisation of the MdPGIP1 from one of these transgenic plants, and an investigation into the inhibitory activity of MdPGIP1 on A. niger, Colletotrichum lupini, Botryosphaeria obtusa and Diaporthe ambigua PGs.

\section{Results}

\subsection{PGIP from fruit of apple cv. Granny Smith inhibits the PGs from C. lupini and A. niger}

The PGIP extract from apple fruit (cv. Granny Smith) inhibited the PGs from the lupin anthracnose pathogen C. lupini (575 units of PGIP activity $\mathrm{mg}^{-1}$ protein; Table 1), and this inhibition was abolished by boiling of the extract (Table 1). Apple fruit PGIP also inhibited the pure endo PG from A. niger (700 units of PGIP activity $\mathrm{mg}^{-1}$ protein; Table 1). These represent significant PGIP activity (69\% and $83 \%$ inhibition of the C. lupini and A. niger PG activities, respectively), indicating that apple PGIP could be considered in a strategy using transgenic lupins against anthracnose disease. However, it was possible that the apple fruit extract could contain a mixture of PGIP proteins with different specificities, and therefore it was necessary to determine how many gene copies are present in this cultivar and to test the product of a specific apple pgip gene. 
Table 1.

Inhibition of $C$. lupini polygalacturonase (PG) and A. niger endo $\mathrm{PG}$ by polygalacturonase inhibiting protein (PGIP) extracts prepared from apple fruit (cv. Granny Smith) and transgenic tobacco plants (MdPGIP)

\begin{tabular}{|l|l|l|}
\hline PGIP $^{\text {a }}$ & PG & PGIP units $/$ mg protein $^{c}$ \\
\hline Apple fruit & C. lupini & $575 \pm 13$ \\
\hline Apple fruit (boiled) & C. lupini & 0 \\
\hline Apple fruit & A. niger & $700 \pm 55$ \\
\hline MdPGIP\#2 & C. lupini & $2400 \pm 80$ \\
\hline MdPGIP\#3 & C. lupini & $1867 \pm 93$ \\
\hline MdPGIP\#4 & C. lupini & $3000 \pm 140$ \\
\hline MdPGIP\#5 & C. lupini & $4200 \pm 240$ \\
\hline MdPGIP\#6 & C. lupini & $2400 \pm 160$ \\
\hline MdPGIP\#7 & C. lupini & $2067 \pm 120$ \\
\hline MdPGIP\#8 & C. lupini & $4867 \pm 260$ \\
\hline MdPGIP\#9 & C. lupini & 0 \\
\hline Untransformed & C. lupini & 0 \\
\hline MdPGIP\#2-\#9 & A. niger & 0 \\
\hline Untransformed & A. niger & 0 \\
\hline
\end{tabular}

\footnotetext{
${ }^{a}$ PGIP extracts were used at $300 \mathrm{ng}$ total protein per reaction in the reducing sugar assay (Berger et al., 2000).

${ }^{\mathrm{b}}$ PGIP extracts from Mdpgip1 transgenic tobacco plants \#2 to \#9.

${ }^{c}$ One unit of PGIP activity was defined as the amount of protein required to reduce the activity of 1 activity unit of PG (RGU) by 50\% (Salvi et al., 1990). One RGU was defined as the amount of $\mathrm{PG}$ enzyme producing one microequivalent of reducing group $\min ^{-1}$ at $30{ }^{\circ} \mathrm{C}$ with $0.25 \%$ polygalacturonic acid as substrate (Salvi et al., 1990).
} 


\subsection{Apple cv. Granny Smith has at least two pgip gene copies}

Southern blot analysis of genomic DNA from apple cv. Granny Smith using a fragment of a previously isolated pgip gene as probe (Arendse et al., 1999) resulted in hybridisation to two restriction fragments each for four different restriction enzymes, namely HindIII (4.3 and $3.8 \mathrm{~kb}$ ), SacI (7.8 and $4.5 \mathrm{~kb}$ ), BglII (3.9 and $0.9 \mathrm{~kb}$ ), and EcoRI ( 8 and $5 \mathrm{~kb}$ ) (Fig. 1, lanes 2, 3, 4 and 7, respectively). The apple pgip probe hybridised to three fragments for the BclI digestion and hybridisation to high molecular weight fragments could not be clearly seen for the BamHI digestion (Fig. 1, lanes 5 and 6, respectively). These results indicated that there are two gene copies and possibly a third in apple cv. Granny Smith. Since there were not multiple pgip copies, as is found in some plant species, such as strawberry (Mehli et al., 2004) or French bean (Frediani et al., 1993), it was considered worthwhile to test the product of a previously sequenced apple pgip gene (Arendse et al., 1999) in transgenic tobacco to determine if it could inhibit the C. lupini PGs.

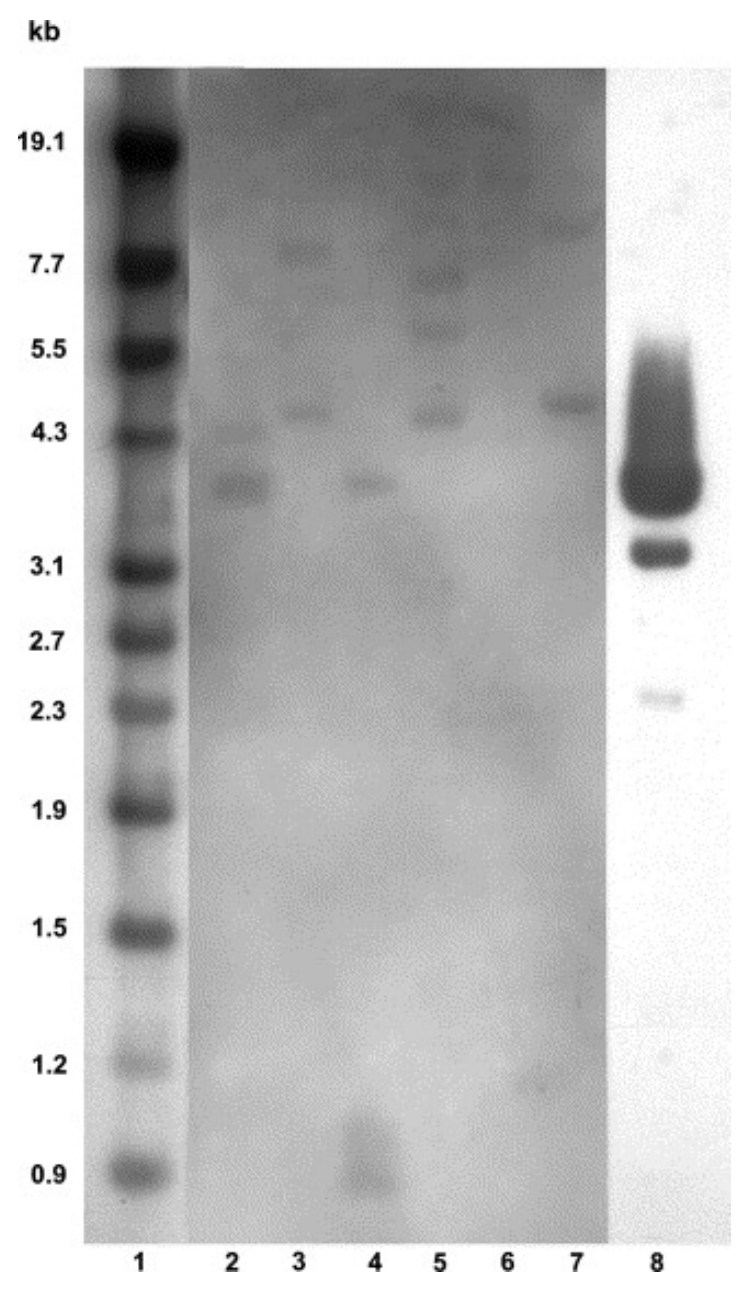

Fig. 1. DNA-blot hybridization of apple pgip to genomic DNA from apple cv. Granny Smith. DNA was digested with HindIII, SacI, BglII, BclI, BamHI and EcoRI (lanes 2-7, respectively), transferred to a nylon membrane and hybridized with a digoxigenin-labeled 
apple pgip probe, using standard DNA-blot procedures. Lane 1 contains Molecular Marker IV (Roche Diagnostics) hybridized separately with digoxigenin-labeled Marker IV. Lane 8 contains plasmid pIPGIP hybridized with the digoxigenin-labeled apple pgip probe.

\subsection{MdPGIP1 extracts from transgenic tobacco inhibit $C$. lupini PGs}

The previously sequenced apple pgip gene (Arendse et al., 1999; Genbank Accession no. DQ185063), termed Mdpgip1, was identical to that isolated independently by Yao et al. (1999) from an apple fruit (cv. Golden delicious) cDNA library (Genbank accession no. U77041). The Mdpgip1 gene was engineered for high-level expression under control of the enhanced CaMV 35S promoter and terminator, as well as the Tobacco Etch Virus (TEV) leader sequence, which enhances the rate of translation (Restrepo et al., 1990), to produce the plasmid pAppRTL2-NcoI. The Mdpgip1 expression cassette was inserted in both possible orientations into a pCAMBIA binary vector to produce pCAM2300appgip1A and pCAM2300-appgip1B. DNA sequencing confirmed that the recombinant plasmids had been correctly constructed.

After Agrobacterium-mediated transformation of tobacco leaf discs, eight independent transgenic tobacco plants were successfully rooted on kanamycin-containing selection media, two derived from pCAM2300-appgip1A (\#2, \#3) and six derived from pCAM2300-appgip1B (\#4-\#9). The transgenic plants were hardened off in the glasshouse and shown to contain the Mdpgip1 transgene using PCR (data not shown; see Methods). The Mdpgip1-specific PCR primers did not amplify a tobacco pgip in the untransformed sample (data not shown). In addition, PCR with Agrobacterium-specific primers confirmed that the first generation Mdpgip1 transgenic tobacco plants were not contaminated with Agrobacterium tumefaciens containing the binary vector that might have escaped the selection (data not shown). MdPGIP extracts from seven of the independent Mdpgip1 transgenic tobacco plants demonstrated PGIP activity against the C. lupini PGs (PGIP activities of $>1867$ units $\mathrm{mg}^{-1}$ protein; Table 1). Mdpgip1 transgenic tobacco plants \#5 and \#8 had the most PGIP activity (4200 and 4867 PGIP units $\mathrm{mg}^{-1}$; Table 1), which represents $63 \%$ and $73 \%$ inhibition of C. lupini PGs, respectively (Table 1). The PGIP extract from the untransformed tobacco plant, as well as the MdPGIP extract from the Mdpgip1 transgenic tobacco plant \#9, demonstrated no inhibition of the C. lupini PGs (Table 1). The lack of PGIP activity in plant \#9, which was shown by PCR to contain the transgene (data not shown), may be due to silencing as a result of the integration site in this independent transgenic plant. MdPGIP extracts from none of the eight Mdpgip1 transgenic tobacco plants, nor the PGIP extract from the untransformed tobacco plant, demonstrated any inhibition of the A. niger endo PG (Table 1). 


\subsection{Purification of active MdPGIP1 to apparent homogeneity from transgenic tobacco}

MdPGIP1-containing fractions from transgenic tobacco plant \#8 were passed through DEAE Sepharose A-25, equilibrated with $20 \mathrm{mM} \mathrm{NaOAc}, \mathrm{pH} 4.7$, in a preparative anion exchange step. MdPGIP1 with a predicted pI of 7 would be positively charged under these conditions, and therefore not be retained by the DEAE-functional groups. The final step in the purification of MdPGIP1 was cation exchange chromatography using HPLC. MdPGIP1 was eluted from the column with a binary gradient from 0 to $1 \mathrm{M} \mathrm{NaCl}$ in $20 \mathrm{mM} \mathrm{NaOAc}, \mathrm{pH}$ 4.7. The protein eluted at $25 \mathrm{~min}$ and at a $\mathrm{NaCl}$ concentration of $0.35 \mathrm{M}$ (panel B, Fig. 2). C. lupini PGs were used to screen the fractions collected during the purification of MdPGIP1 by HPLC for MdPGIP1 activity using the agarose diffusion assay in order to identify which peak in the HPLC elution profile contained the MdPGIP1. A reduction in zone size (well A6, Fig. 2) relative to the activity zone of fungal PGs alone (well A1, Fig. 2), indicated inhibition of the fungal PGs, and thus presence of the MdPGIP1 in the HPLC elution profile (peak B5, Fig. 2). 


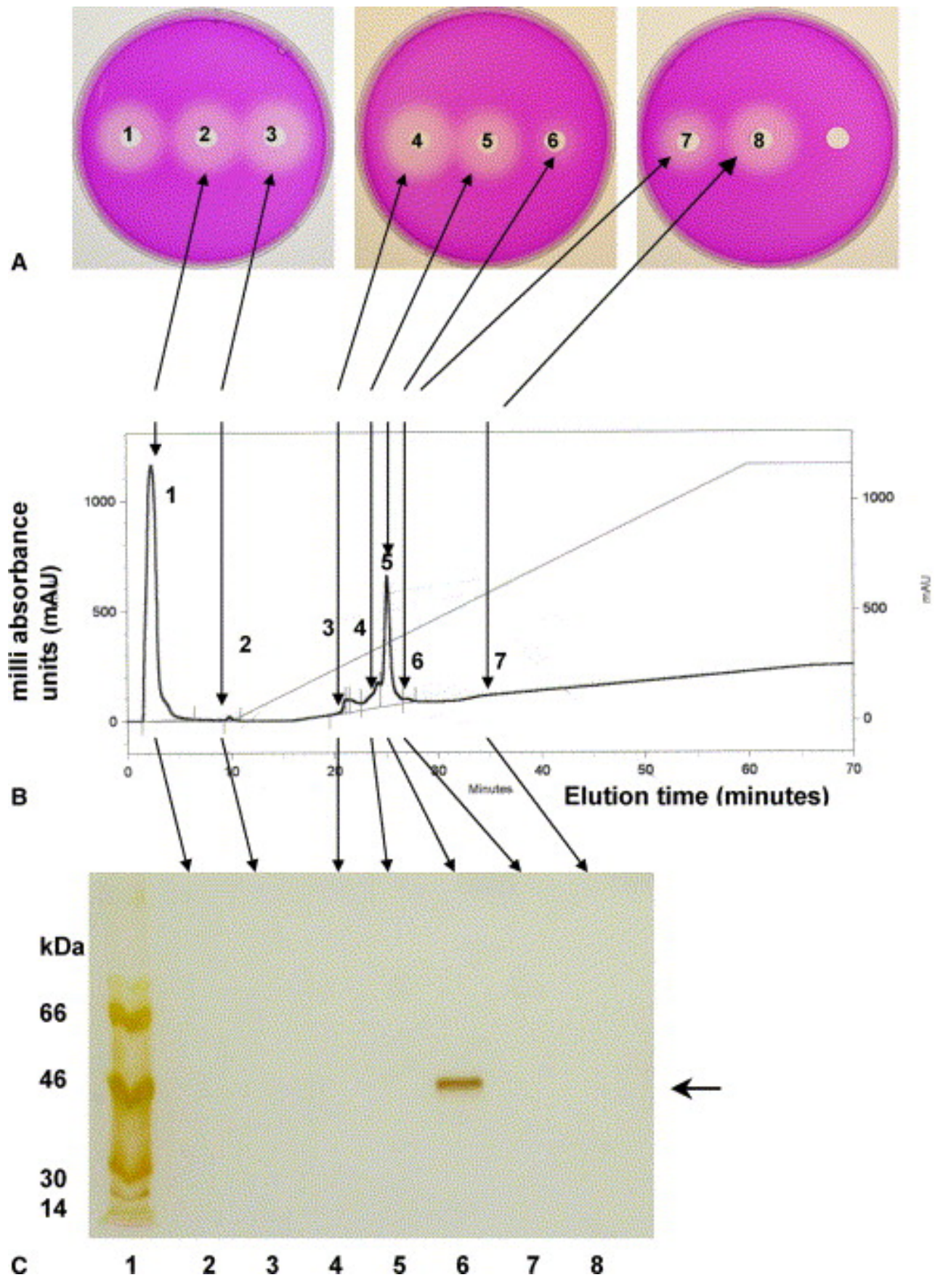

Fig. 2. HPLC purification of the apple polygalacturonase inhibiting protein1 (MdPGIP1) from transgenic tobacco on a sulphopropyl Cosmogel SP cation exchange column. (A) Screening of HPLC fractions for PGIP activity by inhibition of C. lupini polygalacturonases (PGs) using the agarose diffusion assay. (B) HPLC elution profile of fractions (B1-B7) collected during the purification of MdPGIP1. (C) Silver stained SDSPAGE of HPLC fractions collected during the purification of MdPGIP1: Lane C1: Rainbow molecular weight marker (Amersham); Lanes C2-C8: HPLC fractions B1-B7 collected during the purification of MdPGIP1. The arrow indicates the presence of the MdPGIP1 band in HPLC fraction \#5. PGIP activity is obtained from the fraction in peak 
\#5 of the HPLC elution profile (B5) as seen by a reduction in the C. lupini PG activity zone size (A6) relative to the zone size of $C$. lupini PG alone (A1). This correlates with the presence of the protein band at $46 \mathrm{kDa}$ in the silver stained SDS-PAGE (C6), indicating purification of the MdPGIP1 to apparent homogeneity.

MdPGIP1 from peak \#5 in panel B (Fig. 2) appeared to be purified to homogeneity as demonstrated by the presence of a single band with a molecular weight of $46 \mathrm{kDa}$ following SDS-PAGE and silver staining (lane C6, Fig. 2). No bands were detected in any of the other HPLC fractions collected during the purification protocol.

Analysis of the purified MdPGIP1 protein by isoelectric focusing revealed a single band, with a $\mathrm{pI}$ of 8.0, calculated against a series of standard marker proteins ranging from $\mathrm{pI}=3.6$ to $\mathrm{pI}=9.3$ (Fig. 3). N-terminal sequencing demonstrated that the first 15 amino acids of the MdPGIP1 purified in this study were identical to the N-terminus of the mature protein purified from Golden Delicious apple fruit (Yao et al., 1995), as well as the deduced amino acid sequences for the Mdpgip genes cloned from apple cultivar Granny Smith and Golden Delicious apple fruit (Arendse et al., 1999 and Yao et al., 1999) (data not shown). This confirmed the purification of MdPGIP1 from transgenic tobacco, as well as the correct post-translational processing of the $\mathrm{N}$-terminal leader sequence.

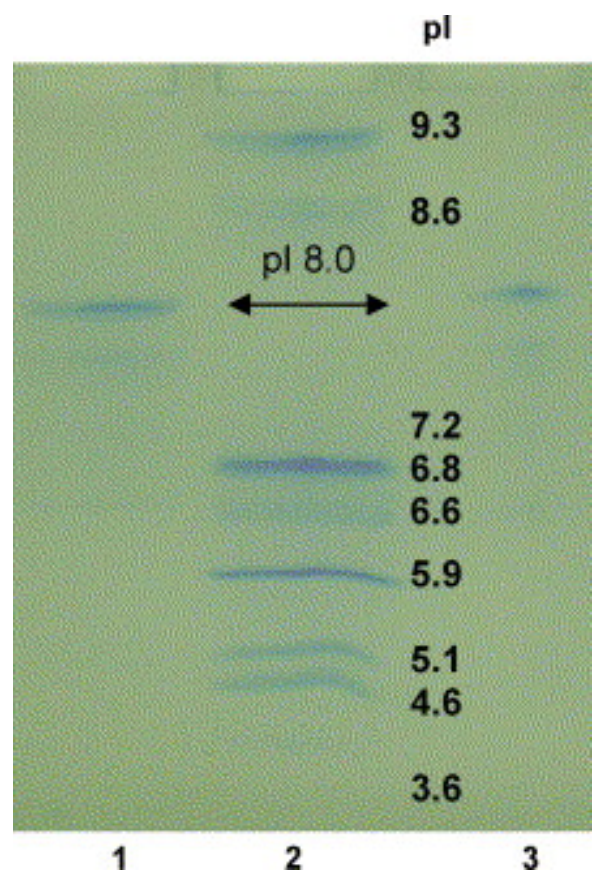

Fig. 3. Vertical isoelectric focusing (IEF) of the apple polygalacturonase inhibiting protein 1 (MdPGIP1) contained in peak \#5 of the HPLC elution profile. IEF was conducted in a $5 \%$ polyacrylamide gel $(8 \times 7) \mathrm{cm}$, with the $\mathrm{pH}$ range from 3 to 10 . Lanes 1 and 3: 20 and 10 ng MdPGIP1, respectively; Lane 2: marker proteins of known pI (Sigma) (amyloglucosidase (3.6), trypsin inhibitor (4.6), lactoglobin (5.1), carbonic 
anhydrase (5.9/6.6), myoglobin (6.8/7.2), lactic dehydrogenase (8.6), trypsinogen (9.3)). Proteins were stained with Gelcode Blue (Pierce). The MdPGIP1 pI of 8.0, as indicated by the black arrow, was calculated from a calibration curve of the standard marker proteins.

\subsection{Purified MdPGIP1 inhibits PGs from C. lupini, B. obtusa and D. ambigua}

The purified MdPGIP1 was active since it inhibited PGs from C. lupini, and PGs from two pathogens of apple B. obtusa and D. ambigua (Fig. 4). The amount of MdPGIP1 required to inhibit the PGs from C. lupini by $50 \%$ was $25 \mathrm{ng}$ (Fig. 4), which was calculated to represent 4000 units of PGIP activity $\mathrm{mg}^{-1}$ of MdPGIP1, whereas approximately half this amount (12.5 ng; Fig. 4) was sufficient to inhibit the PGs from $B$. obtusa and D. ambigua by $50 \%$ ( $\sim 8000$ units of PGIP activity $\mathrm{mg}^{-1}$ of MdPGIP1).

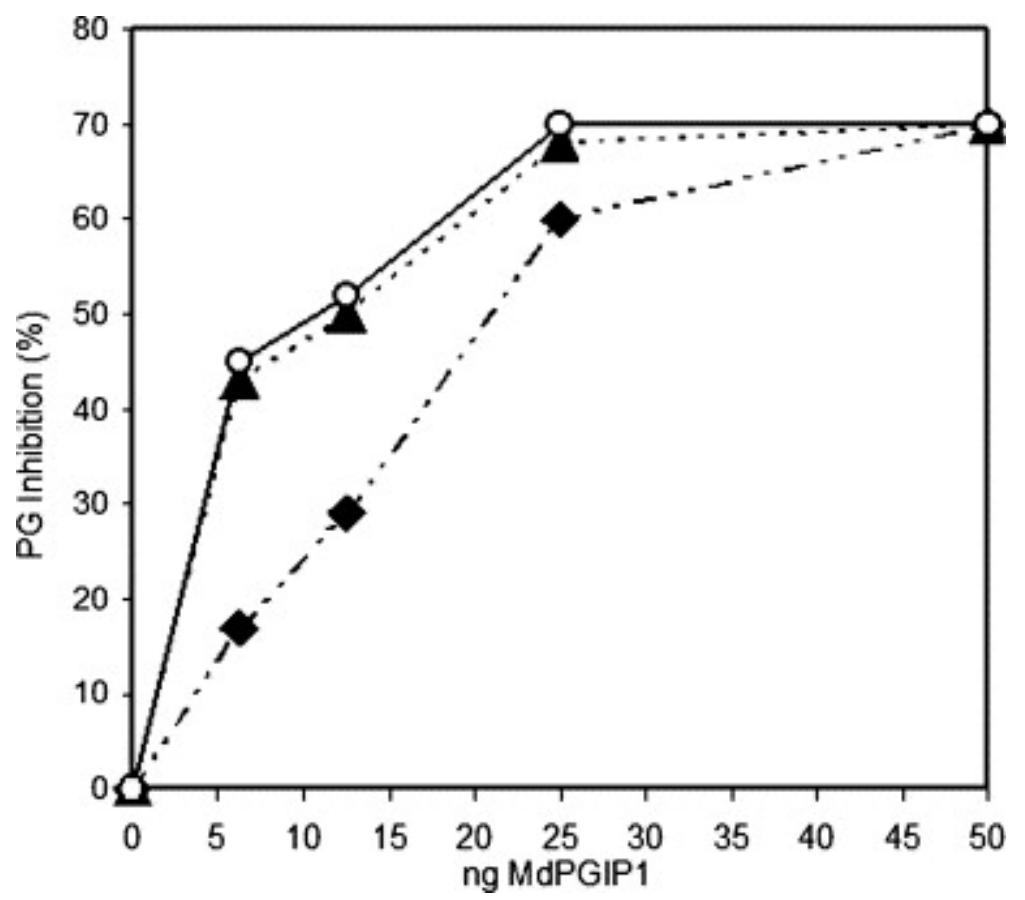

Fig. 4. Inhibition curves of fungal polygalacturonases (PGs) by increasing amounts of apple polygalacturonase inhibiting protein1 (MdPGIP1) purified from transgenic tobacco plant \#8 expressing the Mdpgip1 gene from apple (cultivar Granny Smith). The specific activities of the Colletotrichum lupini PG ( $\bullet)$, Botryosphaeria obtusa PG ( $\mathbf{\Delta})$ and Diaporthe ambigua PG (®) enzymes were 1.22, 53.4 and 1.89 pmol reducing ends $\min ^{-1} \mu \mathrm{g}^{-1}$, respectively. 


\section{Discussion}

Fungi produce many different PGs, each with its own expression pattern in planta and in vitro (Wubben et al., 1999), and in order for plants to interact with all these different PGs, plants have evolved different PGIPs with specific PG recognition capabilities (De Lorenzo et al., 2001). Since plants express more than one PGIP, it is difficult to investigate the inhibitory activity of a single PGIP without going through a laborious purification protocol. The expression of cloned pgip genes in a heterologous system is the convenient way of investigating the inhibitory activities of a single pgip gene product. Expression of PGIP in yeast, other fungal and bacterial systems such as Escherichia coli have proven to be problematic with no real success. The only successful expression of PGIP has been obtained with plant systems. Two options are currently available; by transient expression in Nicotiana benthamiana that has been infected with a modified potato virus X (PVX) (Desiderio et al., 1997 and Leckie et al., 1999) and through the production of stably transformed transgenic plants in which a single pgip gene is being expressed (Desiderio et al., 1997, Berger et al., 2000 and Powell et al., 2000). The latter option was chosen in this study, since Southern blot analysis indicated that the apple cultivar of study (Granny Smith) had a small pgip gene family of two to three members (Fig. 1), and untransformed tobacco leaves did not express an inhibitor of the PGs of interest (Table 1).

Following expression in transgenic tobacco and purification, the MdPGIP1 protein had a molecular mass of approximately $46 \mathrm{kDa}$ (panel C, Fig. 2) which falls within the range of molecular mass observed for all PGIPs purified to date that have not been deglycosylated (37-54 kDa) (De Lorenzo et al., 2001). PGIPs have conserved $N$-glycosylation sites, and the observed heterogeneity in the molecular masses reported in the literature could be due to differential glycosylation (Stotz et al., 1994, Favaron, 2005 and Powell et al., 2000). Chemically deglycosylated PGIPs from pear (Stotz et al., 1993), tomato (Stotz et al., 1994), apple (Yao et al., 1995) and lupin (Costa et al., 1997) all have the same molecular mass of $34 \mathrm{kDa}$, which is consistent with the theoretical $M_{r}$ calculated from the translated nucleotide sequences.

Analysis of the MdPGIP1 purified from transgenic tobacco by isoelectric focusing revealed a single band with a pI of 8 (Fig. 3). Many PGIPs are basic (De Lorenzo et al., 2001). In contrast, Yao et al. (1995) purified an acidic MdPGIP from mature Golden Delicious apple fruit. However, these authors reported difficulty in electro-focussing the PGIP activity in nine fractions from a Mono $\mathrm{S}$ column with $\mathrm{pH}$ ranging from 3.0 to 5.9, which contained a range of MdPGIPs with molecular masses ranging from 44 to $54 \mathrm{kDa}$, out of which the fraction eluting at a $\mathrm{pH}$ of 4.6 exhibited the highest inhibitory activity. The differences in $\mathrm{pI}$ between the acidic MdPGIP purified from apple fruit by Yao et al. (1995) and the basic MdPGIP1 in this study may be due to the fact that they are encoded by different genes.

The argument for two different PGIPs in apple is supported by the fact that a PGIP extract from fruit inhibited both C. lupini PGs and purified A. niger PG (Table 1), whereas none of the MdPGIP1 extracts from the eight Mdpgip1 transgenic tobacco plants 
showed any inhibition of the purified $A$. niger endo PG (Table 1), and neither did the purified MdPGIP1 (data not shown). The inability of an active PGIP to inhibit A. niger endo PG has a precedent, since Stotz et al. (2000) found that pear PGIP (PcPGIP) did not inhibit $A$. niger endo PG. PcPGIP is $97 \%$ identical to MdPGIP1. In contrast, a PGIP purified from apple leaves inhibited the PGs from A. niger (Müller and Gessler, 1993). Southern blotting results indicated that there are at least two copies of the Mdpgip gene found in both Granny Smith (Fig. 1) and Golden Delicious (Yao et al., 1999) cultivars of apple. These data support the hypothesis that there are two active copies of MdPGIP in apple.

Previously, four apple cultivars (Granny Smith, Golden Delicious, Cox's Orange Pippin and Bramley's Seedling) were tested for PGIP activity (Brown, 1984). Cultivar Granny Smith had the highest amount of PGIP activity, whereas cultivar Cox's Orange Pippin had the lowest, and PGIP levels correlated with resistance to the fungus Nectria galligena. In another study, a PGIP from apple leaves inhibited the PGs from A. niger and the economically important fungus Venturia inaequalis (Müller and Gessler, 1993), however these studies did not characterize the pgip gene responsible. The acidic PGIP purified from mature 'Golden Delicious' apple fruit (MdPGIP) showed differential inhibitory activity against five PG isozymes purified from Botrytis cinerea in culture (Yao et al., 1995). The gene encoding this inhibitor is, however, not known.

Black rot, caused by B. obtusa, is a fungal disease that can cause serious losses in apple orchards, especially in warm, humid areas, while D. ambigua causes Daiporthe canker of pome and stone fruit trees (Smit et al., 1997). In the current study, it was demonstrated that the specific product of the Mdpgip1 gene inhibited the PGs of both these economically important pathogens as well as the anthracnose pathogen, which is an important first step in disease control strategies using transgenic apple trees and lupin plants. MdPGIP1 represents an attractive tool for fungal resistance through genetic modification since it is derived from apple fruit that are already consumed raw by the public.

\section{Experimental}

\subsection{Fungal cultures and plant materials}

C. lupini var. setosum strain SHK788 was isolated from diseased Lupinus albus plants (Lotter and Berger, 2005) and is deposited at the National Collection of Fungi of the Agricultural Research Council (ARC) - PPRI, Pretoria, South Africa (culture collection no. PPRI 6128). Cultures of two apple pathogens B. obtusa (culture collection no. CMW227) and D. ambigua (culture collection no. CMW5288) were obtained from the Forestry and Agricultural Biotechnology Institute (FABI), University of Pretoria, South Africa. 


\subsection{Growth of fungi for preparation of PG extracts}

Fungi were grown in liquid medium containing pectin as the carbon source and PG extracts were prepared as described in Berger et al. (2000), except that cultures were first grown in Czapex Dox broth and $1 \mathrm{mg} \mathrm{ml}^{-1}$ ampicillin before transfer to the pectin medium. C. lupini was grown at $23{ }^{\circ} \mathrm{C}$, while B. obtusa and D. ambigua were grown at $25^{\circ} \mathrm{C}$. PG activity and inhibition thereof by PGIPs was measured using the reducing sugar assay as described in Berger et al. (2000). PGs were diluted appropriately so that the 60-min time point was within the linear range of activity. One activity unit (RGU) was defined as the amount of enzyme producing one microequivalent of reducing group $\mathrm{min}^{-1}$ at $30^{\circ} \mathrm{C}$ with $0.25 \%$ polygalacturonic acid as substrate (Salvi et al., 1990).

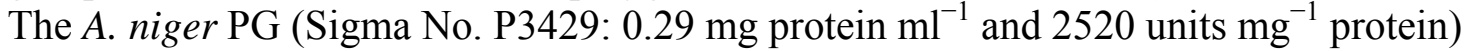
was used at a 1:1500 dilution. The C. lupini, B. obtusa and D. ambigua PGs were used at a specific activities of $1.22,53.4$ and $1.89 \mathrm{pmol}$ reducing ends $\min ^{-1} \mu \mathrm{g}^{-1}$, respectively. The protein concentrations of the PGs were determined using the micro-assay protocol of Bradford (1976). One unit of PGIP activity was defined as the amount of protein required to reduce the activity of 1 RGU of PG by 50\% (Salvi et al., 1990). PGIP activity was also assessed using the agarose diffusion assay (Taylor and Secor, 1988) and expressed as units of PGIP activity as described in Ferrari et al. (2003).

\subsection{DNA blot analysis}

Apple genomic DNA was isolated from apple leaves by the method of Murray and Thompson (1980), digested with restriction enzymes, and Southern blotting was carried out using standard procedures. The probe, made up of a 351-bp internal fragment of apple pgip, was PCR-labelled by incorporation of digoxygenin-11-d-UTP (Roche Diagnostics) using IPGIP ${ }_{\mathrm{L}}$ and $\mathrm{IPGIP}_{\mathrm{R}}$ primers and plasmid pIPGIP as template as describe in Arendse et al. (1999).

\subsection{Construction of Mdpgip1 binary vector for tobacco transformation}

The genomic DNA sequence of a pgip gene from apple (M. domestica cv 'Granny Smith') had previously been determined by degenerate and inverse PCR (Arendse et al., 1999). The genomic sequence lacked introns enabling design of gene-specific PCR primers to amplify the gene from genomic DNA, which had been isolated from apple leaves as described above. PCR primers contained $\mathrm{NcoI}$ and $\mathrm{BamHI}$ sites to facilitate insertion into the pRTL2 vector (APPGIP-L2, 5'-GCAGCCATGGAACTCAAGTTCTC3'; APPGIP-R, 5'-CCCGGATCCATCTGCAGTTGTGGCCATTAC-3'). PCR was carried out using proofreading Pwo polymerase (Roche) as stated by the manufacturer ( $3 \mathrm{ng} \mathrm{I}^{-1}$ template DNA, $5 \mu \mathrm{M}$ each primer, 34 cycles, annealing temperature $\left.58^{\circ} \mathrm{C}\right)$. The PCR product was digested with $\mathrm{NcoI}$ and $\mathrm{BamHI}$ and ligated to the vector pRTL2 (Restrepo et al., 1990); digested with $\mathrm{NcoI}$ and BamHI. The resultant recombinant plasmid pAppRTL2-NcoI contained the Mdpgip1 gene between the enhanced CaMV 35S promoter/Tobacco Etch Virus leader sequence and the CaMV 35S transcription terminator region. DNA sequencing with six different primers showed that the Mdpgip1 gene cloned in pAppRTL2-NcoI was identical to the cDNA sequence of the pgip gene 
from 'Golden Delicious' apples (Yao et al., 1999). The plasmid pAppRTL2-NcoI has HindIII sites flanking the expression cassette, however there is also a HindIII site within the Mdpgip1 gene. A partial HindIII digest (achieved by limiting the magnesium in the restriction buffer) was necessary to clone the Mdpgip1 expression cassette as a HindIII fragment into the plant transformation binary vector pCAMBIA2300 in both orientations to produce pCAM2300-appgip1A and pCAM2300-appgip1B. The Mdpgip1 cassette is in the opposite orientation to the nptII gene in pCAM2300-appgip1A. The cloning junction points between insert and vector were shown to be correct by DNA sequencing (M13 Forward and Reverse primers used for the pCAM2300 constructs; pBI121 sequencing primer \#2 (Berger et al., 2000) and M13 Forward primers used for pAppRTL2-NcoI).

\subsection{Tobacco transformation}

pCAM2300-appgip1A and pCAM2300-appgip1B were transferred to A. tumefaciens LBA4404 by triparental mating. Transconjugants were identified by direct colony PCR using the AP-PGIPL2 and AP-PGIPR primers, and then used for Agrobacteriummediated transformation of leaf discs of tobacco (Nicotiana tabacum) cultivar LA Burley (Horsch et al., 1992). Transgenic plants were selected with $100 \mu \mathrm{g} \mathrm{ml}{ }^{-1}$ kanamycin and hardened off in the greenhouse, together with untransformed plants as controls $\left(18^{\circ} \mathrm{C} / 12 \mathrm{~h}\right.$ night: $28^{\circ} \mathrm{C} / 12 \mathrm{~h}$ day cycle $)$.

\subsection{PCR screening of Mdpgip1 transgenic tobacco}

Small scale isolation of tobacco genomic DNA was performed using the method of Murray and Thompson (1980). Transgenic tobacco were screened for the presence of the Mdpgip1 gene using the primers APPGIP-L2 and APPGIP-R and for recombinant $A$. tumefaciens contamination using the Agrobacterium-specific primers 5'-CCG GCC CGA CGG CAA GCG GC-3' and 5'-CGG CTG GAT GCG CGT CCA G-3' (Grayburn and Vick, 1995).

PCR was conducted in $0.2 \mathrm{ml}$ thin-walled tubes in a MJ Research PTC-200 Peltier Thermal Cycler (DNA engine) with $200 \mu \mathrm{M}$ of each dNTP, $0.5 \mu \mathrm{M}$ of each primer, $1 \mathrm{U}$ DNA polymerase (Promega) and $3 \mathrm{ng} \mathrm{Il}^{-1}$ tobacco genomic DNA template. Reaction conditions for the pgip primers were as follows: $94{ }^{\circ} \mathrm{C}(1 \mathrm{~min}) ; 34$ cycles of $94{ }^{\circ} \mathrm{C}$ $(0.5 \mathrm{~min}), 58^{\circ} \mathrm{C}(0.5 \mathrm{~min}), 72^{\circ} \mathrm{C}(0.75 \mathrm{~min})$; and $72{ }^{\circ} \mathrm{C}(3 \mathrm{~min})$. The conditions for the Agrobacterium-specific primers were the same except that the first denaturation was for $3 \mathrm{~min}$ and the annealing and elongation steps were combined $\left(72^{\circ} \mathrm{C}\right.$ for $\left.1.25 \mathrm{~min}\right)$.

\subsection{Preparation of PGIP extracts from apple fruit and transgenic tobacco expressing the Mdpgip1 gene}

PGIP was extracted from $100 \mathrm{~g}$ apple fruit (cv. Granny Smith) as described in Yao et al. (1995), with the following modifications: the fruit had been stored at $4{ }^{\circ} \mathrm{C}$ for 6 months; the $20 \mathrm{mM}$ sodium acetate (NaOAc) buffer ( $\mathrm{pH}$ 5.2) contained the reducing agent $10 \mathrm{mM}$ $\beta$-mercaptoethanol and $1 \%(\mathrm{w} / \mathrm{v})$ polyvinylpyrrolidone; vacuum filtration through a Whatmann \#4 filter paper was used; $300 \mathrm{mM}$ sodium chloride $(\mathrm{NaCl})$ was added to 
release the PGIP from the cell walls; and the extract was concentrated by $80 \%$ ammonium sulphate precipitation. The yield was $4 \mu \mathrm{g}$ protein $\mathrm{g}^{-1}$ fruit.

Extraction of PGIP from transgenic tobacco was adapted from Desiderio et al. (1997). Tobacco leaf material ( $2 \mathrm{~g}$ ) was ground to a fine powder in liquid nitrogen using a mortar and pestle. Two volumes of $1 \mathrm{M} \mathrm{NaCl}$ in $20 \mathrm{mM} \mathrm{NaOAc}, \mathrm{pH} 4.7$ were added to the leaf material. The extracts were then shaken for $1 \mathrm{~h}$ at $4{ }^{\circ} \mathrm{C}$. Extracts were subsequently centrifuged at $13,000 \mathrm{~g}$ for $20 \mathrm{~min}$ at $4{ }^{\circ} \mathrm{C}$. The pellets were discarded and the supernatants were used in the dialysis step. Samples were dialysed twice for $2 \mathrm{~h}$ at $4{ }^{\circ} \mathrm{C}$ against $20 \mathrm{mM} \mathrm{NaOAc}$ (pH 4.7). A 12,000 MW cut-off dialysis membrane was used. Extracts were subsequently centrifuged at $13,000 \mathrm{~g}$ for $20 \mathrm{~min}$ at $4{ }^{\circ} \mathrm{C}$ and the supernatants stored at $-20^{\circ} \mathrm{C}$.

\subsection{Purification of MdPGIP1 from transgenic tobacco}

The MdPGIP1 was extracted and purified from transgenic tobacco leaf material using an adaptation of the method of Müller and Gessler (1993). Five hundred grams of leaf material was harvested from the tobacco transgenic plants, immediately frozen in liquid nitrogen and subsequently ground to a fine powder using a mortar and pestle. Extraction buffer (1 M NaCl in $20 \mathrm{mM} \mathrm{NaOAc}$, pH 4.7; $5 \mathrm{mM}$ phenylmethylsulfonylfluoride; $5 \mathrm{mM}$ $\beta$-mercaptoethanol; $2 \%(\mathrm{w} / \mathrm{v})$ polyvinylpolypyrrolidone) was added to the homogenised leaf material $(1: 2, \mathrm{w} / \mathrm{v})$. The extract was stirred for $3 \mathrm{~h}$ at $4{ }^{\circ} \mathrm{C}$, centrifuged at $10,000 \mathrm{~g}$ for $30 \mathrm{~min}$ at $4{ }^{\circ} \mathrm{C}$, and the supernatant filtered through Mira-cloth. The supernatant was subjected to an $80 \%$ ammonium sulphate treatment overnight with gentle stirring at $4{ }^{\circ} \mathrm{C}$. The samples were subsequently centrifuged at $10,000 \mathrm{~g}$ for $40 \mathrm{~min}$ at $4{ }^{\circ} \mathrm{C}$. Precipitates were suspended in $20 \mathrm{mM} \mathrm{NaOAc}, \mathrm{pH} 4.7$, containing $1 \mathrm{M} \mathrm{NaCl}$ (twentieth of the original volume) and dialysed overnight at $4{ }^{\circ} \mathrm{C}$ against $20 \mathrm{mM} \mathrm{NaOAc}, \mathrm{pH} 4.7$ (membrane: MW cut-off 6000-8000). The solutions were then centrifuged at $14,000 \mathrm{~g}$ for $1 \mathrm{~h}$ at $4{ }^{\circ} \mathrm{C}$ and the supernatants stored at $4{ }^{\circ} \mathrm{C}$. The pellets were re-extracted in $1 \mathrm{M} \mathrm{NaCl}$ and dialysed as before. Following centrifugation all supernatants were pooled and stirred for 30 min with DEAE Sepharose A-25 (Sigma) that had firstly been washed with $0.5 \mathrm{M}$ $\mathrm{NaOAc}(\mathrm{pH} 5.0)$ and subsequently equilibrated with $20 \mathrm{mM} \mathrm{NaOAc}, \mathrm{pH}$ 4.7. The flow through was collected from the DEAE:PGIP slurry using vacuum filtration and kept at $4{ }^{\circ} \mathrm{C}$. The DEAE Sepharose A-25 was washed with $20 \mathrm{mM} \mathrm{NaOAc}, \mathrm{pH} 4.7$ to remove the remaining PGIP, and the flow through collected by vacuum filtration. The two fractions collected after the DEAE Sepharose A-25 steps were subjected to an $80 \%$ ammonium sulphate treatment as previously described in this section. Following centrifugation, the precipitates were each suspended in $10 \mathrm{ml} 20 \mathrm{mM} \mathrm{NaOAc}, \mathrm{pH} 4.7$ (buffer A) to remove salt ions.

PGIP was purified by HPLC using cation exchange chromatography on a sulphopropyl Cosmogel SP (Nacalai Tesque) packed column $(7.5 \times 75) \mathrm{mm}$. Separation was performed on a Shimadzu model 10 A VP binary gradient HPLC system fitted with a Shimadzu diode array detector, employing a gradient made up of buffer $\mathrm{A}$ and buffer $\mathrm{B}$ (1 $\mathrm{M} \mathrm{NaCl}$ in buffer A) at a flow-rate of $1 \mathrm{ml} \mathrm{min}^{-1}$. The semi-purified preparation from the previous DEAE-Sepharose step was applied to the column and washed with buffer A. 
The PGIP was desorbed from the column with the following program: 0-10 min ( $0 \% \mathrm{~B})$, $10-30 \min (50 \% \mathrm{~B}), 30-35 \mathrm{~min}(100 \% \mathrm{~B})$ and finally re-equilibrated with $0 \% \mathrm{~B}$ for $30 \mathrm{~min}$. The eluted protein was detected by monitoring absorbance from 220 to $300 \mathrm{~nm}$ with the diode array detector. Confirmation of identification was done by PG inhibition studies as described. Fractions $(1 \mathrm{ml})$ were manually collected from 24.5 to $25.5 \mathrm{~min}$, pooled, dialysed and freeze-dried for use in further experiments. The concentration of the purified MdPGIP1 was determined to be $12.5 \mathrm{ng} \mathrm{l}^{-1}$ by co-electrophoresis with a bean PGIP (PvPGIP) concentration standard series, ranging from 25 to $200 \mathrm{ng}$, using SDSPAGE (10\%) (Laemmli, 1970) (data not shown). Purified PvPGIP (from bean pods, using a commercial Italian variety, Borlotto (data not shown)) was used as standards. Polyacrylamide gels were stained with silver nitrate (Blum et al., 1987). Concentrations were determined by comparing the intensities of the MdPGIP1 bands to that of the PvPGIP standards.

\subsection{Characterisation of the MdPGIP1 using SDS-PAGE and native IEF-PAGE}

SDS-PAGE of all of the fractions collected during HPLC purification was performed on $10 \%$ gels and stained with silver nitrate (Laemmli, 1970 and Blum et al., 1987) in order to assess purity and molecular weight of the transgenic MdPGIP1.

The MdPGIP1 contained in peak \#6 of the HPLC elution profile was subjected to vertical isoelectric focusing (IEF). IEF was conducted in a $5 \%$ polyacrylamide gel $(8 \times 7) \mathrm{cm}$, with the $\mathrm{pH}$ range from 3 to 10 (Robertson et al., 1987). Proteins were stained with Gelcode Blue (Pierce). The $\mathrm{pI}$ was calculated from a calibration curve of standard marker proteins of known pI (Sigma).

\subsection{0. $\mathrm{N}$-terminal amino acid sequencing}

A freeze-dried sample of the purified MdPGIP1 was analysed by Edman degradation chemistry for N-terminal amino acid sequencing (Faculte des Sciences, Batiment de chimie, Mont-Saint-Aignan Cedex, France).

\section{References}

Albersheim and Anderson, 1971 P. Albersheim and A.J. Anderson, Proteins from plant cell walls inhibit polygalacturonases secreted by plant pathogens, Proc. Natl. Acad. Sci. USA 68 (1971), pp. 1815-1819.

Arendse et al., 1999 M.S. Arendse, I.A. Dubery and D.K. Berger, Isolation by PCR-based methods of a plant antifungal polygalacturonase-inhibiting protein gene, Electron. $J$.

Biotech. 2 (1999), pp. 152-159. 
Berger et al., 2000 D.K. Berger, D. Oelofse, M.S. Arendse, E. Du Plessis and I.A. Dubery, Bean polygalacturonase inhibiting protein-1 (PGIP-1) inhibits

polygalacturonases from Stenocarpella maydis, Physiol. Mol. Plant P. 57 (2000), pp. 514.

Blum et al., 1987 H. Blum, H. Beier and H.G. Gross, Improved silver staining of plant proteins, RNA and DNA in polyacrylamide gels, Electrophoresis 8 (1987), pp. 93-99.

Bradford, 1976 M.M. Bradford, A rapid and sensitive method for the quantification of microgram quantities of protein utilizing the principal of protein-dye binding, Anal. Biochem. 72 (1976), pp. 248-254.

Brown, 1984 A.E. Brown, Relationship of endopolygalacturonase inhibitor activity to the fungal rot development in apple fruits, Phytopathol. Z. 111 (1984), pp. 122-132.

Cook et al., 1999 B.J. Cook, R.P. Clay, C.W. Bergmann, P. Albersheim and A.G. Darvill, Fungal polygalacturonases exhibit different substrate degradation patterns and differ in their susceptibilities to polygalacturonase-inhibiting proteins, Mol. Plant Microbe In. 12 (1999), pp. 703-711.

Costa et al., 1997 M.M.R. Costa, J. Costa and C.C.P. Ricardo, A Lupinus albus root glycoprotein homologous to the polygalacturonase inhibitor proteins, Physiol. Plantarum 99 (1997), pp. 263-270.

De Lorenzo et al., 2001 G. De Lorenzo, R. D’Ovidio and F. Cervone, The role of polygalacturonase-inhibiting proteins (PGIPs) in defense against pathogenic fungi, Аnnu. Rev. Phytopathol. 39 (2001), pp. 313-335.

Desiderio et al., 1997 A. Desiderio, B. Aracri, F. Leckie, B. Mattei and G. Salvi, Polygalacturonase-inhibiting proteins (PGIPs) with different specificities are expressed in Phaseolus vulgaris, Mol. Plant Microbe In. 10 (1997), pp. 852-860.

English et al., 1971 P.D. English, J.B. Jurale and P. Albersheim, Host-pathogen interactions II: Parameters affecting polysaccharide-degrading enzyme secretion by Colletotrichum lindemuthianum grown in culture, Plant Physiol. 47 (1971), pp. 1-6.

Favaron, 2005 F. Favaron, Gel detection of Allium porrum polygalacturonase-inhibiting protein reveals a high number of isoforms, Physiol. Mol. Plant Pathol. 58 (2005), pp. 239-245.

Ferrari et al., 2003 S. Ferrari, D. Vairo, F.M. Ausubel, F. Cervone and G. De Lorenzo, Tandemly duplicated Arabidopsis genes that encode polygalacturonase-inhibiting proteins are regulated coordinately by different signal transduction pathways in response to fungal infection, Plant Cell 15 (2003), pp. 93-106. 
Frediani et al., 1993 M. Frediani, R. Cremonini, G. Salvi, C. Caprari, A. Desiderio, R. D'Ovidio, F. Cervone and G. De Lorenzo, Cytological localization of the pgip genes in embryo suspensor cells of Phaseolus vulgaris L, Theor. Appl. Genet. 87 (1993), pp. 369373.

Grayburn and Vick, 1995 W.S. Grayburn and B.A. Vick, Transformation of sunflower (Helianthus anuus L.) following wounding with glass beads, Plant Cell Rep. 14 (1995), pp. 285-289.

Horsch et al., 1992 R.B. Horsch, J.E. Fry, N. Hoffman, J. Neidermeyer, S.G. Rogers and R.T. Fraley, Leaf disc transformation. In: S.B. Gelvin, R.A. Schilperoort and D.P.S. Verna, Editors, Plant Molecular Biology Manual, A5, Kluwer Academic Publishers, Dordrecht (1992), pp. 1-9.

Karr and Albersheim, 1970 A.L. Karr and P. Albersheim, Polysaccharide-degrading enzymes are unable to attack plant cell walls without prior action by a "wall-modifying enzyme", Plant Physiol. 46 (1970), pp. 69-80.

Laemmli, 1970 U.K. Laemmli, Cleavage of structural proteins during the assembly of the head of Bacteriophage T4, Nature 227 (1970), pp. 680-685.

Leckie et al., 1999 F. Leckie, B. Mattei, C. Capodicasa, A. Hemmings, L. Nuss, B. Acrari, G. De Lorenzo and F. Cervone, The specificity of polygalacturonase-inhibiting protein (PGIP): a single amino acid substitution in the solvent-exposed $\beta$-strand/ $\beta$-turn region of the leucine-rich repeats (LRRs) confers new recognition capability, Embo J. 18 (1999), pp. 2352-2363.

Lotter and Berger, 2005 H.C. Lotter and D.K. Berger, Anthracnose of lupins in South Africa is caused by Colletotrichum lupini var. setosum, Australasian Plant Pathol. 34 (2005), pp. 385-392.

Mehli et al., 2004 L. Mehli, J.G. Schaart, T.D. Kjellsen, D. Hong Tran, E.M.J. Salentijn, H.J. Schouten and T.-H. Iversen, A gene encoding a polygalacturonase-inhibiting protein (PGIP) shows developmental regulation and pathogen-induced expression in strawberry, New Phytologist 163 (2004), pp. 99-110.

Müller and Gessler, 1993 M. Müller and C. Gessler, A protein from apple leaves inhibits pectinolytic activity of Venturia inequalis in vitro. In: B. Fritig and M. Legrand, Editors, Mechanisms of Plant Defense Responses, Kluwer Academic Publishers, Dordrecht (1993), pp. 68-71.

Murray and Thompson, 1980 M.G. Murray and W.F. Thompson, Rapid isolation of high molecular weight plant DNA, Nucleic Acids Res. 8 (1980), pp. 4321-4325.

Powell et al., 2000 A.L.T. Powell, J. van Kan, A. ten Have, J. Visser, L.C. Greve, A.B. Bennett and J.M. Labavitch, Transgenic expression of pear PGIP in tomato limits fungal colonisation, Mol. Plant Microbe In. 13 (2000), pp. 942-950. 
Restrepo et al., 1990 M.A. Restrepo, D.D. Freed and J.C. Carrington, Nuclear transport of plant potyviral proteins, Plant Cell 2 (1990), pp. 987-998.

Robertson et al., 1987 E. Robertson, H.K. Dannelly, P.J. Malloy and H.C. Reeves, Rapid isoelectric focusing in a vertical polyacrylamide minigel system, Anal. Biochem. 167 (1987), pp. 290-294.

Salvi et al., 1990 G. Salvi, F. Giarrizzo, G. De Lorenzo and F. Cervone, A polygalacturonase-inhibiting protein in the flowers of Phaseolus vulgaris L, Plant Physiol. 136 (1990), pp. 513-518.

Smit et al., 1997 W.A. Smit, B.D. Wingfield and M.J. Wingfield, Vegetative incompatibilty in Diaporthe ambigua, Plant Pathol. 46 (1997), pp. 366-372.

Stotz et al., 1993 H.U. Stotz, A.L.T. Powell, S.E. Damon, L.C. Greve, A.B. Bennett and J.M. Labavitch, Molecular characterization of a polygalacturonase inhibitor from Pyrus communis L cv Bartlett, Plant Physiol. 102 (1993), pp. 133-138.

Stotz et al., 1994 H.U. Stotz, J.J.A. Contos, A.L.T. Powell, A.B. Bennett and J.M. Labavitch, Structure and expression of an inhibitor of fungal polygalacturonases from tomato, Plant Mol. Biol. 25 (1994), pp. 607-617.

Stotz et al., 2000 H.U. Stotz, J.G. Bishop, C.W. Bergmann, M. Koch and P. Albersheim, Identification of target amino acids that affect interactions of fungal polygalacturonases and their plant inhibitors, Physiol. Mol. Plant P. 56 (2000), pp. 117-2130.

Taylor and Secor, 1988 R.J. Taylor and G.A. Secor, An improved diffusion assay for quantifying the polygalacturonase content of Erwinia culture filtrates, Phytopathology 78 (1988), pp. 1101-1103.

Wubben et al., 1999 J.P. Wubben, W. Mulder, A. ten Have, J.A.L. van Kan and J. Visser, Cloning and partial characterisation of endopolygalacturonase genes from Botrytis cinerea, Appl. Environ. Microb. 65 (1999), pp. 1596-1602.

Yao et al., 1995 C.L. Yao, W.S. Conway and C.E. Sams, Purification and characterisation of a polygalacturonase-inhibiting protein from apple fruit, Phytopathology 85 (1995), pp. 1373-1377.

Yao et al., 1999 C.L. Yao, W.S. Conway, R. Ren, D. Smith, G.S. Ross and C.E. Sams, Gene encoding polygalacturonase inhibitor in apple fruit is developmentally regulated and activated by wounding and fungal infection, Plant Mol. Biol. 39 (1999), pp. 12311241. 